\title{
Pharmaciana
}

Vol.10, No.2, July 2020, Page. $231-238$

ISSN: 2088 4559; e-ISSN: 24770256

DOI: $10.12928 /$ pharmaciana.v10i2.16311

\section{The effect of Zingiber cassumunar Roxb rhizome extract on in vitro phagocytic activity and lymphocyte proliferation}

\author{
Nurkhasanah Mahfudh $^{* 1}$, Nanik Sulistyani ${ }^{2}$, Dinda Anindya Sabillah ${ }^{1}$ \\ ${ }^{I}$ Department of Analytical Pharmacy and Medicinal Chemistry, \\ Faculty of Pharmacy, Universitas Ahmad Dahlan \\ Jl.Prof. Dr. Soepomo, Janturan, Yogyakarta, Indonesia \\ ${ }^{2}$ Department of Pharmaceutical Biology, Faculty of Pharmacy, \\ Universitas Ahmad Dahlan \\ Jl.Prof.Dr. Soepomo, Janturan, Yogyakarta, Indonesia
}

\begin{abstract}
Zingiber cassumunar Roxb (Bengal ginger) is among the medicinal plants possessing immunomodulatory potentials. It contains curcumin and some volatile compounds that reportedly exhibit immunomodulatory activities. This study set out to examine and determine the effect of ethyl acetate fraction of $Z$. cassumunar rhizome extract on phagocytic activity of macrophages and lymphocyte proliferation in vitro. Z. cassumunar rhizomes were macerated with $96 \%$ ethanol solvent and then fractionated using ethyl acetate. Macrophages and lymphocytes were isolated from male Balb/C mice; the former was tested for its phagocytic activity using latex bead assay, while the latter was examined for its proliferation using the MTT assay. The extracts were prepared with different concentrations: 25,50 , and $100 \mu \mathrm{g} / \mathrm{m}$, and the effects of these treatments on the test mice were compared to the negative control group. The results showed that the ethyl acetate fraction of $Z$. cassumunar rhizome extract elevated the phagocytic activity of macrophages, as evident from an increase in active phagocytes (SFA) and phagocytosis index. Extracts at $100 \mu \mathrm{g} / \mathrm{mL}$ produced the highest percentage of SFA and phagocytic index. Also, the ethyl acetate fraction of $Z$. cassumunar rhizome extract could increase lymphocyte proliferation significantly compared to the negative control $(\mathrm{p}<0.05)$. Overall, these activities prove that $Z$. cassumunar rhizomes have the potential as an immunomodulatory agent.
\end{abstract}

Keywords: immunomodulator, macrophage, lymphocyte proliferation, Zingiber cassumunar

\footnotetext{
*Corresponding author:

Nurkhasanah Mahfudh

Department of Analytical Pharmacy and Medicinal Chemistry

Faculty of Pharmacy, Universitas Ahmad Dahlan

Jl Prof. Dr. Soepomo, Janturan, Yogyakarta, Indonesia

Email: nurkhas@gmail.com
} 


\section{INTRODUCTION}

Zingiber cassumunar Roxb, or Bengal ginger, is a traditional herbal medicine used for treating various diseases, including diarrhea, fever, stomachache, rheumatism, asthma, phlegm, worm infection, and jaundice. Previous studies have reported that the rhizome of this plant contain antioxidant (Bua-in and Paisooksantivatana, 2009; Chanwitheesuk et al., 2005; Pal et al., 2011; Vankar et al., 2006), immunomodulatory (Chairul et al., 2009), anti-inflammatory (Somchit and Shukriyah, 2003), and antibacterial properties (Kamazeri et al., 2012). Essential oil and curcumin derivatives are believed to be the components responsible for this rhizome's antioxidant and immunomodulatory activities (Nagano et al., 1997). Essential oils are primarily composed of sabinene, pinene, caryophyllene oxide, and caryophyllene (Bhuiyan et al., 2008).

Prior scholars have confirmed that the administration of Z. cassumunar rhizome extract can increase the phagocytic capacity and NO secretion of macrophages, indicating its effectiveness as an immunostimulant for, among others, adjuvant therapy in malaria (Nurkhasanah et al., 2017). Furthermore, curcumin in this rhizome is known for its immunostimulant properties that can increase Reactive Oxygen Species (ROS), which in turn activates signals involving Peroxism ProliferatorActivated Gamma Receptors (PPAR-) and Nrf2 (Nurmasari et al.,2014).

In the immune system, some cells, like macrophages, play an essential role in maintaining immune response to invaders. An increase in macrophage activity represents improved immune responses against bacteria, viruses, and other invaders (Hirayama et al., 2018). In addition to having a long life span and several granules, macrophages release various substances, including lysozyme, complement, interferon, and cytokines, all of which contribute to nonspecific and specific immune defenses. Besides, macrophages play a significant part in the immune system, i.e., as effector cells and antigen-presenting cells (APC); the latter is a crucial step in cell signaling and activation of the adaptive immunity (Taylor et al., 2005). Lymphocytes determine the development of adaptive responses to a specific antigen (LaRosa and Orange, 2008).

The current study was designed to find the active fraction of Zingiber cassumunar extract responsible for high immunostimulant activity. This activity was analyzed from the capability of this fraction to increase macrophage activity and lymphocyte proliferation.

\section{MATERIALS AND METHODS \\ Materials}

The sample used in this study was the rhizome of Zingiber cassumunar Roxb obtained from a local market in Yogyakarta and identified in the Laboratory of Biology, Universitas Ahmad Dahlan. The rhizome was dried and ground and then sifted using siever No 40.

\section{Methods}

\section{Preparation of ethyl acetate fraction}

A total of 200 grams of $Z$. cassumunar rhizome powder was macerated using $96 \%$ ethanol with a ratio of 1:5 at room temperature. The results of the maceration were evaporated in a rotary evaporator at a temperature of $50^{\circ} \mathrm{C}$, continued with evaporation using a water bath until a concentrated extract was formed. Afterward, the extract was diluted using the n-hexane solvent, and the nonsoluble fraction was diluted with ethyl acetate. The soluble ethyl acetate fraction was separated and evaporated to create ethyl acetate fraction.

\section{Thin-layer chromatography (TLC)}

The components of the fraction were determined using the TLC method and curcumin compounds as a standard. (Boscolo et al., 2003). The mobile phase used was chloroform: dichloromethane (3.25: 6.75), while the stationary phase was silica gel GF254. UV $365 \mathrm{~nm}$ and UV $254 \mathrm{~nm}$ were used as the component detectors (Yusuf and Nurkhasanah, 2015). 


\section{Macrophage phagocytosis assay}

The macrophages were isolated from peritoneal macrophages of Balb/C strain mice. All test animals in this study were treated following the principle of animal welfare, and every method used in this study has been approved by the research ethics committee of Universitas Ahmad Dahlan, with reference number 011804063 .

The isolated macrophages were incubated for 24 hours. Afterward, in the phagocytosis test, each well was added with $200 \mu \mathrm{L}$ of medium containing $5 \times 10^{5}$ cells and incubated in a $5 \% \mathrm{CO}_{2}$ incubator at $37^{\circ} \mathrm{C}$ for 1 hour. Then, each well was added with $800 \mu \mathrm{L}$ of complete medium and incubated in a $5 \%$ $\mathrm{CO}_{2}$ incubator at $37^{\circ} \mathrm{C}$ for 24 hours.

The medium was discarded, and each sample was added with $500 \mu \mathrm{l}$ of the ethyl acetate fraction of $Z$. cassumunar rhizome extract and incubated in a 5\% CO2 incubator at $37^{\circ} \mathrm{C}$ for 60 minutes. Afterward, each well was washed three times with $200 \mu$ of PBS to remove any latex beads that were not phagocytosed. The plate was dried and fixed with absolute methanol for 30 seconds, and then the methanol was removed and dried for 10 minutes before added with $50 \mu \mathrm{l}$ of Giemsa for 20 minutes. The remaining Giemsa was discarded, rinsed with water, and then dried. The coverslip was placed on the object glass, and the macrophages were observed under a microscope with 100x magnification (Nurkhasanah et al., 2017).

\section{Lymphocyte proliferation assay}

The lymphocyte cells were isolated from the spleen organ of the Balb/C mice. The spleen tissue was aseptically isolated and transferred to a $50-\mathrm{mm}$ petri dish containing $10 \mathrm{~mL}$ of RPMI to produce a lymphocyte suspension. Afterward, this suspension was added with $5 \mathrm{~mL}$ of ammonium chloride tris buffer and allowed to stand at room temperature for 15 minutes. Ten $\mathrm{mL}$ of the suspension was added with RPMI and centrifuged at $3,200 \mathrm{rpm}, 4^{\circ} \mathrm{C}$ for 4 minutes. The precipitate was separated from the supernatant and washed twice with RPMI, then added with a complete medium. Lymphocyte cells were counted using a hemocytometer.

A total of $100 \mu \mathrm{l}$ of lymphocytes with a concentration of $1.5 \times 10^{6}$ cells $/ \mathrm{mL}$ were distributed into a 96-wells microplate. This microplate underwent a three-stage incubation: first, each well was added with $10 \mu \mathrm{l}$ of the ethyl acetate fraction of $Z$. cassumunar rhizome extract and incubated in a $5 \% \mathrm{CO}_{2}$ incubator at $37^{\circ} \mathrm{C}$ for 24 hours. Second, each well was added with $10 \mu \mathrm{l}$ of PHA (Phytohaemaglutinin) and incubated again for four days in a $\mathrm{CO}_{2}$ incubator. Third, each well was added with $10 \mu \mathrm{l}$ of MTT 5 $\mathrm{mg} / \mathrm{mL}$, followed by four hours of incubation at $37^{\circ} \mathrm{C}$. The living cells would react with MTT, producing a purple color. After a stopper reagent $(10 \% \mathrm{SDS}$ in $50 \mu \mathrm{HCl} 0.01 \mathrm{~N})$ was added to each well, the microplate was stored at room temperature for 12 hours in a dark condition. Then, the absorbance values were assessed using an ELISA reader at a wavelength of $595 \mathrm{~nm}$ (Adhila et al., 2019).

\section{RESULTS AND DISCUSSION}

The fractionation of the ethanol extract of $Z$. cassumunar rhizome using ethyl acetate produced a percent yield of $19.9 \%$. The TLC results detected two curcumin derivatives in this fraction. Figure 1, the chromatogram of the ethyl acetate fraction, shows five spots under the UV light $254 \mathrm{~nm}$. An active curcumin compound could be detected in Rf 0.22 (Figure 1) with the same color of standard. A previous study (Rafi et al., 2011) showed that the elution of $Z$. cassumunar rhizome extract resulted in five spots, proving that this extract indeed contains curcumin. Another curcumin derivative, namely dimethoxy curcumin, was also detected in the extract, with an Rf value of 0.37 . 


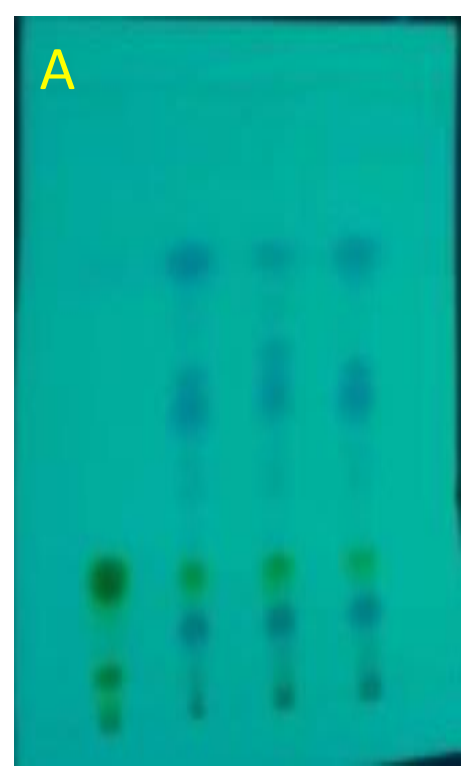

a $\quad$ b $\quad c \quad c \quad d$

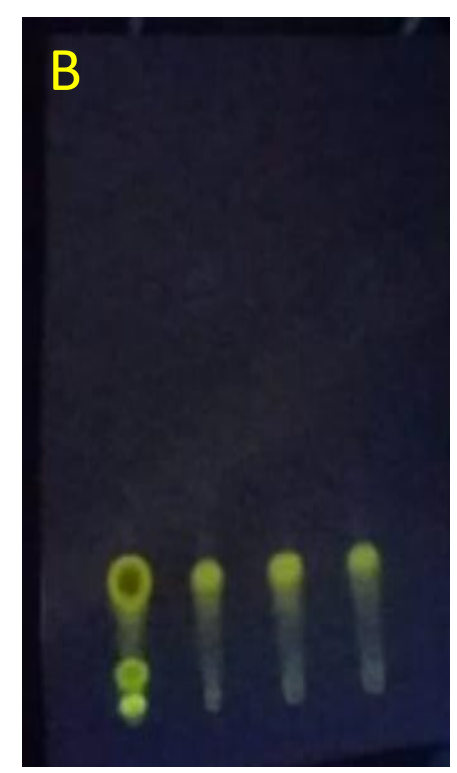

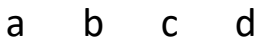

Figure 1. The TLC profiles of Zingiber cassumunar extract under (A) UV 254 and (B) UV 366 lights (curcumin standard (a), chloroform extract (b), ethyl acetate fraction (c), and methanol extract (d) of $Z$. cassumunar rhizome)

\section{Increased phagocytic activity}

An increase in phagocytic activity was expressed as the percentage of active phagocytic cells and phagocytosis index. Active phagocytic cells were active macrophages that phagocytosed the latex beads. The phagocytic activities of macrophages after treatment with the ethyl acetate fraction of $Z$. cassumunar rhizome are presented in Table 1.

Table 1. The phagocytic activities of macrophages treated with the ethyl acetate fraction of Zingiber cassumunar extract

\begin{tabular}{lll}
\hline Treatments & Active Phagocytic Cells (\%) & Phagocytosis Index \\
\hline Control & $9.54 \pm 0.238$ & $1.22 \pm 0.029$ \\
Group $25 \mu \mathrm{g} / \mathrm{mL}$ & $31.63 \pm 1.289^{*}$ & $1.60 \pm 0.059^{*}$ \\
Group $50 \mu \mathrm{g} / \mathrm{mL}$ & $42.54 \pm 0.951^{*}$ & $1.35 \pm 0.009 *$ \\
Group $100 \mu \mathrm{g} / \mathrm{mL}$ & $52 . .57 \pm 0.893^{*}$ & $1.87 \pm 0.024 *$ \\
\hline
\end{tabular}

*Significantly different from the control group $(\mathrm{p}<0.05)$

Table 1 shows that the percentage of active phagocytic cells increased with the increase in extract concentration. The growing number of active phagocytic cells was detected in the $100 \mathrm{ug} / \mathrm{mL}$ treatment group. Compared to the control group, the phagocytosis index of the treatment groups also significantly increased $(\mathrm{p}<0.05)$.

The results showed that the ethyl acetate fraction of $Z$. cassumunar extract prepared in three different concentrations, i.e., 25, 50, and $100 \mu \mathrm{g} / \mathrm{mL}$, could increase the phagocytic activity of 
macrophages. Also, the curcumin content is a proven immunostimulant that can increase Reactive Oxygen Species (ROS), which in turn, activates signals involving Peroxism Proliferator-Activated Gamma Receptors (PPAR) and Nrf2. Activation of these two signals on monocytes and macrophages increases CD36 expression and, consequently, phagocytic macrophage (Nurmasari et al., 2014). Macrophage activation is also mediated by $\mathrm{Fc}$ (fragment crystallizable) receptor activation, a protein found on the surface of certain cells in the immune system including macrophage. The activation of $\mathrm{Fc}$ receptors results the activation of macrophage (Taylor et al., 2005; Underhill and Ozinsky, 2002).

This hypothetical mechanism is supported by previous research, in which Z. cassumunar has been found to increase nitrite oxide (NO) production in mice infected by P. berghei and, subsequently, the phagocytosis activity of macrophages (Nurkhasanah et al., 2019).

\section{Lymphocyte proliferation after treatment}

The lymphocyte proliferation assay was used to determine the response of regulatory components in the immune system. Lymphocytes can distinguish foreign bodies from their own tissues because they have receptors located on the surface of the cell, Toll Receptor Cell (TCR) cells (Baratawidjaya, 2006). Lymphocytes, when stimulated with antigens, will activate and produce lymphokines and proliferate. The dendritic cells in the spleen produce antigens that are captured by $\mathrm{T}$ cells in other parts of the body, produce cytokines, and stimulate lymphocyte proliferation and differentiation. The results are summarized in Table 2.

Table 2. The absorbance of lymphocyte cells of male Balb/C mice in the MTT test after receiving the ethyl acetate fraction of Zingiber cassumunar extract

\begin{tabular}{ll}
\hline \multicolumn{1}{c}{ Treatments } & \multicolumn{1}{c}{ Absorbance } \\
\hline Control & $0.12 \pm 0.019$ \\
Group $25 \mu \mathrm{g} / \mathrm{mL}$ & $0.364 \pm 0.041^{*}$ \\
Group $50 \mu \mathrm{g} / \mathrm{mL}$ & $0.274 \pm 0.077^{*}$ \\
Group $100 \mu \mathrm{g} / \mathrm{mL}$ & 0.1560 .074
\end{tabular}

*Significantly different from the control group $(\mathrm{p}<0.05)$

Lymphocytes, as a specific immune response, are related to $\mathrm{T}$ cells. $\mathrm{T}$ cell lymphocytes also play a role in the activation and proliferation of B cells in producing antibodies and in the activation of macrophages in phagocytosis (Vogt and Schulte, 2011). Increasing lymphocyte proliferation by antigens involves this following mechanism: the antigen binds to the $\mathrm{T}$ cell surface receptor and will induce IL-1 expression from APC, which activates G-protein to produce an enzyme called phospholipase C. The enzyme phospholipase $\mathrm{C}$ will hydrolyze phosphatidylinositol bisphosphate (PIP2) to produce glycerol (DAG) and inositol triphosphate (IP3) as a reactive product. Then, the amount of $\mathrm{Ca}^{2+}$ released into the cytoplasm increases due to stimulation by IP3. Because an increase in $\mathrm{Ca}^{2+}$ will stimulate protein kinase $\mathrm{C}$ and 5-lipoxygenase enzymes. The result of the IL-2 stimulation will produce and activate $\mathrm{B}$ cells $\mathrm{T}$ cells for proliferation (Otsuka et al., 2006).

Table 2 shows that the ethyl acetate fraction of $Z$. cassumunar extract increased the proliferation of lymphocyte $(\mathrm{p}<0.05)$, but this correlates negatively with the concentration of the administered extract. If the number of lymphocytes is adequate to eliminate invaders, there will be a feedback mechanism suppressing the proliferation.

Furthermore, the Stimulation Index Proliferation (SIP) was calculated using the absorbance value obtained using the ELISA reader (Norian et al., 2015). SIP compares lymphocytes proliferation between the treatment group and control group (Table 3 ). 
Table 3. Stimulation Index Proliferation (SIP) of lymphocytes after receiving the ethyl acetate fraction of Zingiber cassumunar extract

\begin{tabular}{ll}
\hline Treatments & Stimulation Index Proliferation \\
\hline Group $25 \mu \mathrm{g} / \mathrm{mL}$ & $9.441 \pm 1.445$ \\
Group $50 \mu \mathrm{g} / \mathrm{mL}$ & $6.318 \pm 2.663$ \\
Group $100 \mu \mathrm{g} / \mathrm{mL}$ & $2.254 \pm 2.581$
\end{tabular}

Table 3 shows that the ethyl acetate fraction of $Z$. cassumunar extract at 25 and $50 \mathrm{mg} / \mathrm{l}$ could increase lymphocyte proliferation, but when administered at $100 \mathrm{mg} / \mathrm{l}$, the extract did not induce such a significant increase compared to the normal. If lymphocyte proliferation activity increases, it will not only increase cytotoxic T cells, but it will also increase Th cells that help the response of B cells in binding to two specific antigens. An increase in lymphocyte proliferation of the test animals also takes place after receiving some secondary metabolites of herbal medicines (Boscolo et al., 2003; Ioannone et al., 2013). Treatments using ingredients containing some flavonoids are proven to increase lymphocyte proliferation through the activation of NFkB transcription factor and modulating of some cytokines (Ioannone et al., 2013). A previous study also confirms that Zingiber cassumunar extract increases the expression of interleukin-10 and interleukin-14 (Nurkhasanah et al., 2019).

\section{CONCLUSION}

The ethyl acetate fraction of the Zingiber cassumunar rhizome can increase the phagocytic activity of macrophages and lymphocyte proliferation, indicating its potential development as an immunomodulatory agent.

\section{ACKNOWLEDGEMENT}

The authors would like to thank the Ministry of Research, Technology and Higher Education for funding this research through the Post Graduate Research Team scheme in 2018.

\section{REFERENCES}

Adhila, G., Nurkhasanah, N., \& Sulistyani, N. (2019). In vitro immunomodulatory activity test of Bengle rhizoma extract (Zingiber cassumunar Roxb.): phagocytic activity of macrophages and lymphocyte proliferation in mice. Pharmaciana, 9(2), 211. https://doi.org/10.12928/pharmaciana.v9i2.12881.

Armiyant, Y., Utami, W. S., \& Ameliana, L. (2014). Pengembangan ekstrak rimpang bangle (Zingiber cassumunar Roxb) terstandar menjadi granul effervesen sebagai terapi ajuvan untuk mencegah komplikasi pada malaria. In laporan penelitian (Vol. 1). Fakultas Kedokteran Universitas Jember.

Baratawidjaya. (2006). Imunologi Dasar. fakultas Kedokteran Universitas Indonesia.

Bhuiyan, M. N. I., Chowdhury, J. U., \& Begum, J. (2008). Volatile constituents of essential oils isolated from leaf and rhizome. Bangladesh $J$ Pharmacol, 3(2), 69-73. https://doi.org/10.3329/bjp.v3i2.844.

Boscolo, P., Del Signore, A., Sabbioni, E., Di Gioacchino, M., Di Giampaolo, L., Reale, M., Conti, P., Paganelli, R., \& Giaccio, M. (2003). Effects of resveratrol on lymphocyte proliferation and cytokine release. Annals of Clinical and Laboratory Science, 33(2), 226-231.

Bua-in, S., \& Paisooksantivatana, Y. (2009). Essential oil and antioxidant activity of Cassumunar Ginger ( Zingiberaceae : Zingiber montanum ( Koenig ) Link ex Dietr .) Collected from various parts of Thailand. Kasetsart Journal Natural Science, 43(3), 467-475.

Chairul, Praptiwi, \& Chairul, S. M. (2009). Phagocytosis effectivity test of phenylbutenoid compounds isolated from Bangle ( Zingiber cassumunar Roxb .) Rhizome. Biodiversitas, 10(1), 40-43. https://doi.org/10.13057/biodiv/d100108. 
Chanwitheesuk, A., Teerawutgulrag, A., \& Rakariyatham, N. (2005). Screening of antioxidant activity and antioxidant compounds of some edible plants of Thailand. Food Chemistry, 92(3), 491-497. https://doi.org/10.1016/j.foodchem.2004.07.035.

Hirayama, D., Iida, T., \& Nakase, H. (2018). The phagocytic function of macrophage-enforcing innate immunity and tissue homeostasis. International Journal of Molecular Sciences, 19(92), 1-14. https://doi.org/10.3390/ijms19010092.

Ioannone, F., Miglio, C., Raguzzini, A., \& Serafini, M. (2013). Flavonoids and immune function. In Diet, Immunity and Inflammation (pp. 379-415). Elsevier. https://doi.org/10.1533/9780857095749.3.379.

Kamazeri Tg, S. A. T., Samah, O. A., Taher, M., \& Susanti, D. (2012). Antimicrobial activity and essential oils of Curcuma aeruginosa, Curcuma mangga , and Zingiber cassumunar from Malaysia. Asian Pacific Journal of Tropical Medicine, 5(3), 202-209. https://doi.org/10.1016/S19957645(12)60025-X.

LaRosa, D. F., \& Orange, J. S. (2008). Lymphocytes. Journal of Allergy and Clinical Immunology, 121(2 SUPPL. 2), 364-369. https://doi.org/10.1016/j.jaci.2007.06.016.

Nagano, T., Oyama, Y., Kajita, N., Chikahisa, L., \& Nakata, M. (1997). New curcuminoids suffering from isolated oxidative using from Zingiber cassumunar and Protect Study Cells Stress : A FlowCytometric Rat Thymocytes. Japanese Journal of Pharmacology, 75(4), 363-370.

Norian, R., Delirezh, N., \& Azadmehr, A. (2015). Evaluation of proliferation and cytokines production by mitogen-stimulated bovine peripheral blood mononuclear cells. Veterinary Research Forum: An International Quarterly Journal, 6(4), 265-271.

Nurkhasanah, N., Sulistyani, N., \& Sofyan, A. D. (2019). The effect of ethyl acetate fraction of Bangle (Zingiber Cassumunar Roxb.) Rhizome extracts on interleukin-10 and interleukin-14 expression in vitro. Advances in Health Sciences Research, 18, 37-42. https://doi.org/10.2991/adics-phs19.2019.8.

Nurkhasanah, Santoso, D. R., \& Fauziah, R. (2017). The immunomodulatory effect of Zingiber cassumunar ethanolic extract on phagocytic activity, nitrit oxide and reaxtive oxygen intermediate secretions of macrophage in mice. IOP Conf. Series: Materials Science and Engineering, 259, 110. https://doi.org/10.1088/1757-899X/259/1/012007.

Nurkhasanah, Sulistyani, N., \& Noorlina. (2019). In vitro activity of immunomodulator of $n$-hexane fraction of bangle (Zingiber cassumunar roxb.) ethanol extract. Research Journal of Chemistry and Environment, 23(8), 62-64.

Nurmasari, D. P., Utami, W. S., \& Sulistyaningsih, E. (2014). The Role of Bangle Extract (Zingiber Cassumunar Roxb .) on Nitric Oxide and Malondialdehyde of Plasmodium beghei-infected Mice). E-Jurnal Pustaka Kesehatan, 2(3), 403-408.

Otsuka, H., Ikeya, T., Okano, T., \& Kataoka, K. (2006). Activation of lymphocyte proliferation by boronate-containing polymer immobilised on substrate: The effect of boron content on lymphocyte proliferation. European Cells and Materials, 12(2), 36-43. https://doi.org/10.22203/eCM.v012a04

Pal, J., Pal, S., Prakash, O., Batra, M., \& Kumar, A. (2011). Hepatoprotective and antioxidant activity of Zingiber chrysanthum Rosec . rhizomes. Asian Journal of Traditional Medicines, 6(6), 242251.

Rafi, M., Rohaeti, E., Miftahudin, A., \& Darusman, L. K. (2011). Differentiation of Curcuma longa, Curcuma xanthorrhiza and Zingiber cassumunar by thin layer chromatography fingerprint analysis. Indonesian Journal of Chemistry, 11(1), 71-74. https://doi.org/10.22146/ijc.21423.

Somchit, N. M., \& Shukriyah, N. M. (2003). Antiinflammatory property of ethanol and water extracts of Zingiber zerumbet. Indian Journal of Pharmaclogy, 35(3), 181-182.

Taylor, P. R., Martinez-Pomares, L., Stacey, M., Lin, H.-H., Brown, G. D., \& Gordon, S. (2005). Macrophage Receptors and Immune Recognition. Annual Review of Immunology, 23(1), 901-944. https://doi.org/10.1146/annurev.immunol.23.021704.115816.

Underhill, D. M., \& Ozinsky, A. (2002). Phagocytosis microbes: Complexity in Action. Annual Review 
of Immunology, 20(1), 825-852. https://doi.org/10.1146/annurev.immunol.20.103001.114744

Vankar, P. S., Tiwari, V., Singh, L. W., \& Swapana, N. (2006). Antioxidant properties of some exclusive species of Zingiberaceae family of Manipur. Electronic Journal of Some Exclusive Species of Zingiberaceae Family of Manipur, 5(2), 1318-1322.

Vogt, R., \& Schulte, P. A. (2011). Evaluation of immune responses. In Evaluation of immune responses (Issue 13). IARC scientific publications.

Yusuf, F. M., \& Nurkhasanah. (2015). Evaluasi kadar kurkumin dalam kamu tradisional kunir asam yang dijual di pasar kota gede bulan Februari 2015. Pharmaceutical Science Research, 2(3), 115123. https://doi.org/10.7454/PSR.V2I3.3342. 